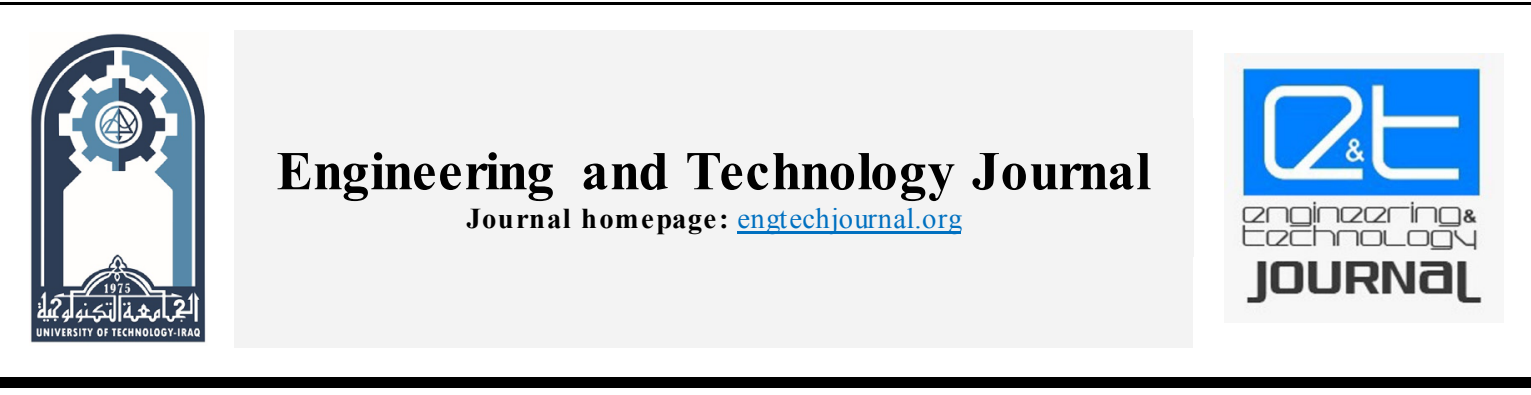

\title{
Slope Stability Analysis of Haditha Dam after Earthquake using Geo-Studio Software
}

\author{
Mohammed K. Malik ${ }^{a^{*}}$, Ibtisam R. Karim ${ }^{\mathrm{b}}$ \\ ${ }^{a}$ Civil Engineering Dept., University of Technology, Baghdad, Iraq, 42365@student.uotechnology.edu.iq \\ b Civil Engineering Dept., University of Technology, Baghdad, Iraq, 40049@uotechnology.edu.iq \\ *Corresponding author. \\ Submitted: $30 / 10 / 2020$ \\ Accepted: $30 / 12 / 2020$ \\ Published: $25 / 04 / 2021$

\section{K E Y W O R D S} \\ Haditha Dam, \\ GeoStudio, Slope \\ stability, QUAKE/W

\begin{abstract}
A B S T R A C T
The current study is designed to analyze theslope stability of Haditha damwhich is an earth-fill dam constructed on the Euphrates River in the middle-west of Iraq. Finite element modeling was used in thepresent study to analyze the combined seepage and post-earthquake slope stability of Haditha earth dam. The maximum water level of a steady seepage case was considered to evaluate seepage. - Three different water levels (maximum, normal, and minimum) wereapplied, and nine differentequilibrium slope stability limits were used to analyze the upstream and downstream slopes of the dam with three horizontalmaximum accelerations. The input data given to the software are the dam geometry and its material properties with the earthquake records in the year2019. The dam was investigated by considering the water in the reservoir to be at maximum, minimum and normal water levels in its actual design. It was concluded that the dam is on the safe side in terms of stability even though the change in the earthquake's conditions in Iraq.
\end{abstract} \\ How to cite this article:M.K. Malik andI.R. Karim, "Slope Stability Analysis of Haditha Dam after Earthquake using Geo-Studio \\ Software," Engineering and Technology Journal, Vol. 39 Part A, No. 04 pp. 519-613, 2021. \\ DOI: https://doi.org/10.30684/etj.v39i4A.1909 \\ This is an open access article under the CC BY 4.0 license http://creativecommons.org/licenses/by/4.0
}

\section{INTRODUCTION}

Any dam failure or accident to dam can cause a potential hazard to property and lives of millions of people who dwell downstream of the dam and also other live stock. Hence safety of the dams is a very important aspect of safeguarding national investment. So, several studies have dealt with the issue of dams' safety. Irzooqi[1] studied and analyzed the seepage problem in the downstream area of Haditha dam in Al-Anbar governorate on Euphrates River especially in front of two stations on the right side. It was concluded that the main source of the seepage at the first site is a leakage of reservoir water through the foundation. At a second site, the main source is reservoir water, which seeps under the foundation grout curtain through the channels made by the dissolution of the gypsums formations. 
Salih[2]studied the performance of the right side of Haditha Dam.After the second stage of filling the dam reservoir to the level of $129 \mathrm{~m}$, the problem of leakage appeared on the right side and with a drainage ranging from (13 to 15$) \mathrm{l} / \mathrm{s}$. This problem has been studied and analyzed in order to evaluate the efficiency of the asphaltic concrete barrier and the grout curtain, depending on the field information monitored by the researcher and the information obtained from the maintenance and operation department ofHaditha dam. The field monitoring process showed that the highest seepage discharge is $20 \mathrm{l} / \mathrm{s}$ at the storage level of $145.11 \mathrm{~m}$. In order to evaluate the efficiency of the asphaltic concrete and the grout curtain, several methods have been adopted for this purpose. These methods are groundwater and seepage measurements and chemical analysis. The results indicated that the asphaltic concrete is in good condition and works efficiently. As for the grout curtain, it is in good condition.Al - Tae'e[3] studied the dynamic response of embankments and dams using the finite element method. Three constitutive models were used for uncoupled analysis to estimate the dam response under an earthquake loading. These models are namely, Linear, Equivalent linear and Non-linear models. The lower San Fernando dam was chosen as a case study. A computer program for predicting and analyzing the first and third models were established. This program was developed originally from a computer code-namedDLEARN established at Stanford University. By comparing the failure shape of the dam with the actual failure, it was found that the bounding surface plasticity model visualized the realistic behavior of the dam under the dynamic loading rather than the equivalent linear and elastic linear models.Elgamal et al. [4] investigated the effect of rigid model container size on earth-fill dam response in the dynamic centrifuge. Numerical simulations were conducted for two centrifuges earthfill dam models, one with a non-remediated loose saturated sand foundation and the other with a remediated case. The computational model was formulated using a solid-fluid fully coupled finite element code. It was concluded that the dam displacements (both lateral and vertical) are not significantly different between the original and the wider foundational models for both benchmark and remediated cases.In a series of twelve independent Geotechnical centrifuge physical modeling tests, KorhanAdalier and Sharp[5] studied the seismic behavior of a zoned earth dam with saturated sandy soil foundation under moderate earthquake conditions. Several miniature accelerometers, pore pressure sensors, and displacement gauges were used in the soil model to monitor soil response during and after shaking. The effect of various parameters such as the thickness, location, and depth of the liquefiable layer on the seismic behavior of the dam is studied. Valuable insights are provided into the dynamic behavior of the embankment-foundation systems employed.A dynamic analysis on zoned earthdams subjected to earthquake excitation was carried out by Hadi [6] that the pore water pressure, effective stresses and displacements are determined. The finite element method is used and, via its sub-programs SEEP / W and QUAKE / W, the computer program Geo-Slope is being used in the study. Khassa Chai Dam (Iraq), which is located on the Khassa Chai River, is considered a case study.It was concluded that at the base of the core, the value of the pore water pressure produced is greater than that of the upper dam sections.Elasaad, et al [7] studied the effect of earthquakes on the stability of AL-Basel dam on Al-Abrash River in Tartous city in Syria with an analytical study by Finite Element Method. They have set a numerical model suitable by using Slope/W and Quake/W software. The results of the simulation are summarized in calculation factors of safety for verification of the final stability of the dam under the effect of different intensity earthquakes. Comparison between the two cases static and dynamic models shows the effect of the shear variables of the soil angle of internal friction and the tendency of slops dam and the different situations of the lake water levels and the high of the dam in addition to the effect of the construction material of the dam on the stability of the body of the dam. They also studied the effect of seismic amplification resulting from the body of the dam on both horizontal and vertical components of seismic acceleration.AlShamary[8] studiedto assess the water seepage during the Haditha dam (Iraq) using the computer software (SEEP/ W, 2012). The results obtained from the software were compared with the actual field data on the seepage amount for years (1989 - 2017) and with the water level in the dam reservoir for different periods. The results of the comparison give an idea of the efficiency of the dam protection against seepage. The results displayed that the asphaltic diaphragm in good condition and efficient on the right and left sides of the dam.

The main target of the research is to check the safety of post-earthquake slope stability of Haditha dam after the change in seismic conditions in Iraq in recent years by using GeoStudio software with its subprograms SEEP/W, SLOPE/W, and QUAKE/W. 


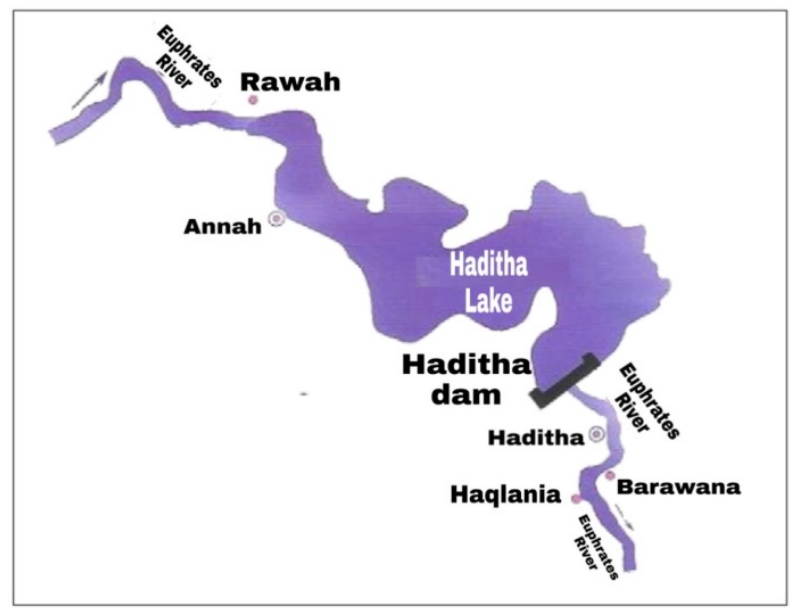

Figure 1: Location of Haditha dam on Euphrates River.

The length of the dam barrier is $9064 \mathrm{~m}$ ( $8875 \mathrm{~m}$ dam and $189 \mathrm{~m}$ hydroelectric station), the dam layout is shown in Figure 2, and more specifications are shown in Table II.Figure 3 shows the main materialsof the dam[11].

TABLEII: Technical specifications for Haditha dam[8].

\begin{tabular}{lc}
\hline TABLEII: Technical specifications for Haditha & dam[8]. \\
\hline Total length of the dam and hydroelectric station & $9064 \mathrm{~m}$ \\
\hline Length of the right-bank stretch & $3310 \mathrm{~m}$ \\
\hline The channel stretches of the dam & $580 \mathrm{~m}$ \\
\hline The stretch of the left bank, shown in Figure 2 & $4985 \mathrm{~m}$ \\
\hline The dam height & $57 \mathrm{~m}$ \\
\hline Length of the dam at top & $8923 \mathrm{~m}$ \\
\hline Width of dam base & $325 \mathrm{~m}$ \\
\hline Top width & $20 \mathrm{~m}$ \\
\hline Elevation at top & $154 \mathrm{~m} . \mathrm{a} . \mathrm{s} .1$. \\
\hline Operational level & $147 \mathrm{~m} . \mathrm{a} . \mathrm{s} .1$. \\
\hline Storage size of operational level & $8.28 \mathrm{Billion} \mathrm{m}^{3}$ \\
\hline Surface area of storage at operational level & $500 \mathrm{~km}$ \\
\hline Flood level & $150.2 \mathrm{~m} . \mathrm{a} . \mathrm{s} .1$. \\
\hline Storage size at flood level & 9.8 Billion $\mathrm{m}^{3}$ \\
\hline Surface area of storage at flood level & $567 \mathrm{~km}$ \\
\hline Min. operational level & $129.5 \mathrm{~m} . \mathrm{a} . \mathrm{s} .1$. \\
\hline Min. water level & $112 \mathrm{~m} . \mathrm{a} . \mathrm{s} .1$. \\
\hline Dead storage & $0.23 \mathrm{Billion} \mathrm{m}^{3}$ \\
\hline
\end{tabular}

The most seismically dangerous zone for Haditha Dam is the northwest link of the lower Euphrates line which is capable of generating earthquakes with the following seismic standards [12]:

- Richter magnitude $\mathrm{M}_{\max }=5.5$

- Intensity of earthquake at dam site $\mathrm{I} \approx$ on MSK scale.

- $0.25 \mathrm{~g}$ maximum horizontal acceleration.

Richter magnitude is a measure of the strength of earthquakes, developed by Charles F. Richter and presented in his landmark 1935 paper, which is called the "magnitude scale" [13].

Medvedev-Sponheuer-Karnik scale, also known as the MSK or MSK-64, is a macroseismic intensity scale used to evaluate the severity of ground shaking on the basis of observed effects in an area of the earthquake occurrence [13].

TABLEIII lists the material properties of the various zones in the dam body and the foundation thereof. [12]. 


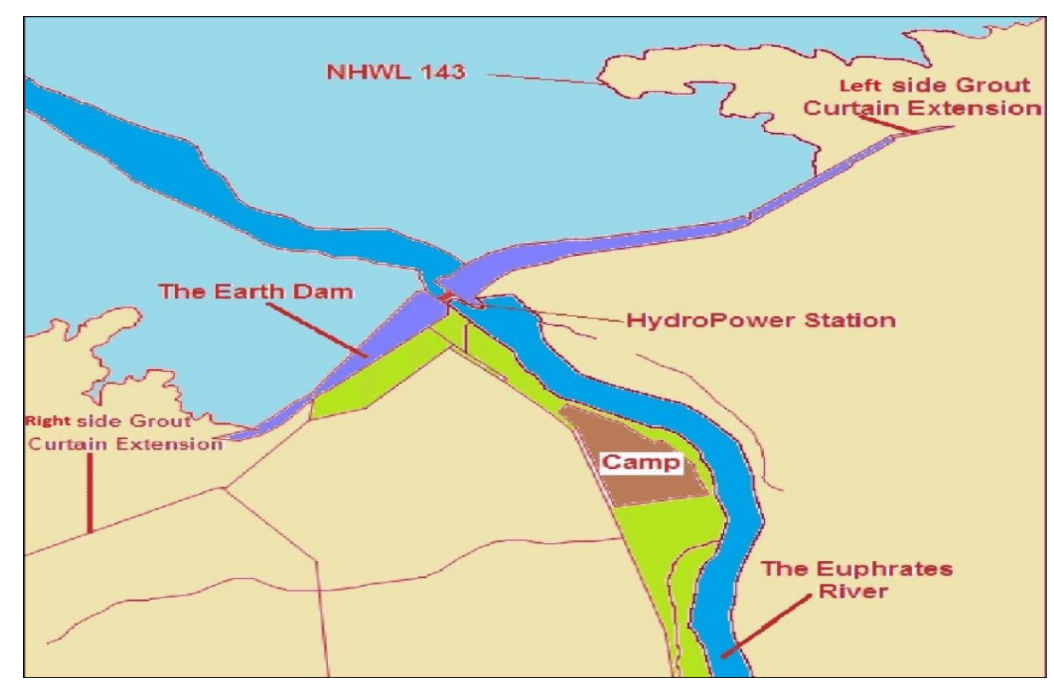

Figure 2: Haditha dam layout [11].

TABLEIII: Material properties of Haditha dam, [12].

\begin{tabular}{|c|c|c|c|c|c|}
\hline Material & $\begin{array}{c}\text { Unit } \\
\text { weight } \\
\left(\mathrm{kN} / \mathbf{m}^{3}\right) \\
\end{array}$ & $\begin{array}{c}\text { Cohesion } \\
\text { (kPa) }\end{array}$ & $\emptyset^{\circ}$ & $\begin{array}{c}\text { Coefficient of } \\
\text { Permeability } k_{h} \\
(\mathrm{~m} / \mathrm{s})\end{array}$ & $\begin{array}{c}\text { Saturated } \\
\text { water content } \\
\% \\
\end{array}$ \\
\hline mealy dolomite & 22 & 30 & 26 & $1.15^{*} 10^{-7}$ & 0.29 \\
\hline clay & 18.7 & 40 & 15 & $2.31 * 10^{-8}$ & 0.47 \\
\hline dolomite-limestone & 22 & 150 & 32.5 & $1.15^{*} 10^{-8}$ & 0.29 \\
\hline $\begin{array}{c}\text { rock muck sandy } \\
\text { gravel }\end{array}$ & 17 & 0 & 28.5 & $2.31 * 10^{-6}$ & 0.39 \\
\hline dolomite & 20.3 & 0 & 31.5 & $1.15^{*} 10^{-8}$ & 0.35 \\
\hline Width of dam base & $325 \mathrm{~m}$ & & & & \\
\hline $\begin{array}{c}\text { Asphaltic concrete } \\
\text { diaphragm }\end{array}$ & 17.7 & 0 & 30.97 & $1 * 10^{-9}$ & 0.16 \\
\hline
\end{tabular}



Figure 3: The main materials of Haditha dam by the author with GeoStudio according to Dams and Reservoirs Authority (as built) [12]. 


\section{Haditha DaM Seepage Analysis}

A dolomite core controlsSeepage via Haditha dam and inside the core extends an asphaltic-concrete diaphragm that starts from the base of the dam to almost its top to cutoff the seepage lines. This core consists of dolomite rocks with hydraulic conductivity ranges from (0.1-1) m/day. Ninety cross sections are stated along the axis of the dam body on the right and left sides each of ninety meters length as shown in Figure 4. The cross section of station 32 was chosen to calculate the seepage because it is the most exposed to the pressure of the reservoir water due to its proximity to the river bed and the high depth of the water in it in addition to the availability of the piezometer reading and the seepage value of this station.

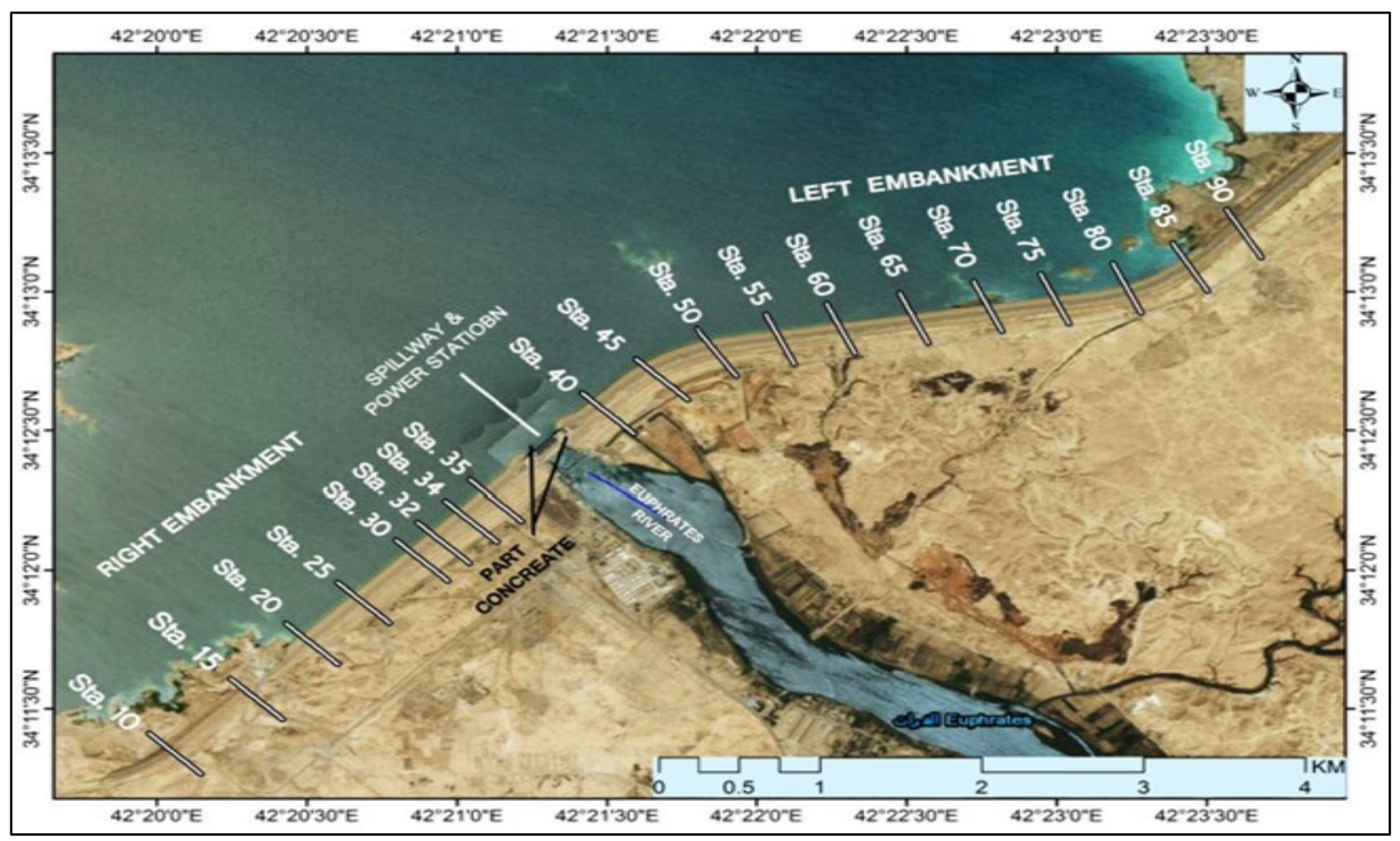

Figure 4: Locations of the stations on the body of the Haditha dam, [8].

The software SEEP / W2012 is used to analyze seepage through and under the dam. In Figure 5, the finite element mesh used for the analysis of the maximum water level is shown. The mesh contains, with (3204 elements) and (1695 nodes), higher-order six-nodded triangular elements. The nodes of the upstream boundary are designated as head boundaries, with a total head equal to the reservoir water level. A zero discharge (no flow) is designated as the bottom line at the toe.Figures 6 and 7 present the water head variation and pore water pressure through the dam body, respectively. It is clear from Figure 6 that the central dolomite core, asphaltic-concrete diaphragm, and grout curtain causes significant lowering of the phreatic line and exit at the dam toe, which is safe for stability because the phreatic line not intersects with a downstream face; thus, the sloughing phenomenon of the downstream not happen.Figure 7 confirms that the pore water pressure on the internal surface of downstream side slope is far away from downstreamand the seepage through the dam is within the historical cases of seepage failure in (Rice)[14]which ensures the stability of the downstream against seepage failure. 


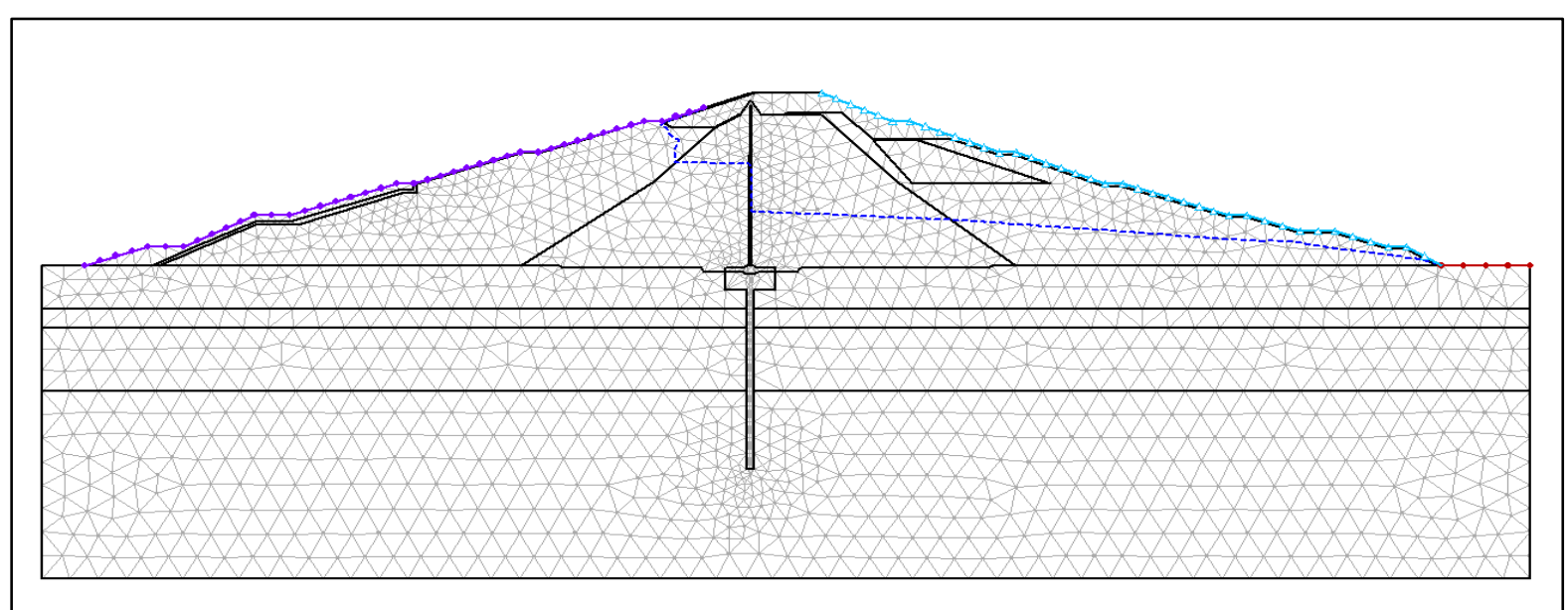

Figure 5: Typical finite element mesh for seepage analysis by GeoStudio.

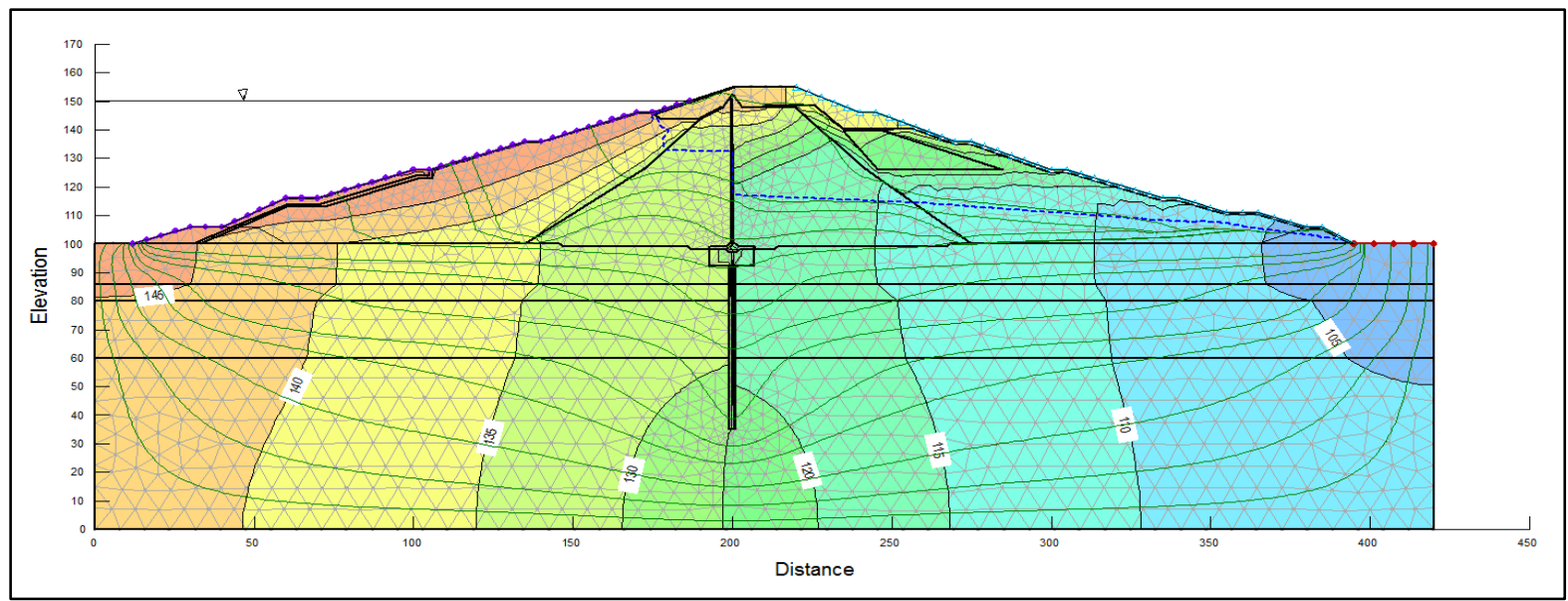

Figure 6: Water head variation and flow line through the dam body.

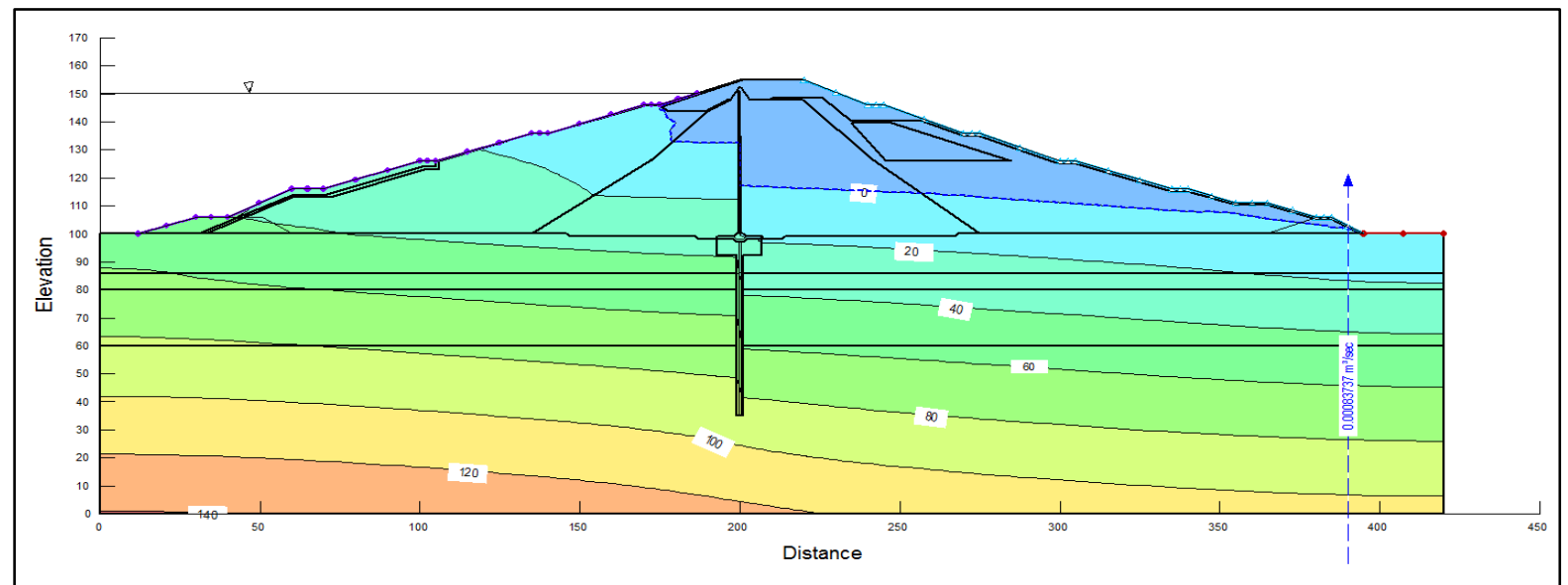

Figure 7: Pore water pressure through the dam body with flux section.

\section{HADITHA DAM INITIAL STATIC STRESS ANALYSIS}

It is necessary to establish initial static stress conditions before the dynamic analysis is performed. A separate step within the QUAKE / W software computed the initial static stress of Haditha dam subjected to the force of gravity. The initial static stress outcomes measured were very rational. Then, in the dynamic analysis part of the QUAKE / W software, the determined results of the initial static stress and initial pore water pressure were imported. 


\section{DYNAMIC ANALYSIS}

The dam is analyzed by the software QUAKE / W after the seepage analysis is completed, based on results obtained from the SEEP / W program. The finite element mesh used for the analysis is shown in Figure 5. Higher-order six-nodded triangular elements are used in the mesh. The left and right vertical limit conditions on nodes are considered to be free to move in the horizontal direction in dynamic analysis, but they are fixed in the vertical direction. It is assumed that the boundary conditions are fixed in vertical and horizontal directions along the horizontal base of the foundation.Allowing horizontal motion at the end of the issue, but the not vertical motion, is considered acceptable. The justification is that there would be the same horizontal motion beyond the ends of the problem as at the ends of the mesh. Another way of viewing this is that there is no resistance to lateral motion beyond the ends of the mesh. However, shearing in the soil will prevent or keep the vertical displacement at the end of the issue to a minimum. Consequently, as stated in GeoSlope International Ltd, only vertical displacements are defined at the end of the issue.[10].

According to the Technical report on Haditha Dam in 2020; for the damage of all 11 seismic stations located on the dam for technical reasons [15], It is assumed that the dam is exposed to earthquakes with acceleration-time history is shown in Figure 8 [16], that recorded by Al-Rutba station with maximum acceleration 0.134g in 30 seconds and Baghdad station with maximum acceleration 0.161g in 36 seconds in Al-Anbar and Baghdad governorates, respectively, which are recorded in 2019. Figure 9 shows the positions of seismic monitoring stations in Iraq.

For calibration purposes, themaximum horizontal acceleration of $0.375 \mathrm{~g}$ is taken as earthquakes. This value is recommended [6] that resultesfrom multiplying the safety factor of 1.5 by the value of the design acceleration of the dam 0.25 to know the conditions of dam failure.
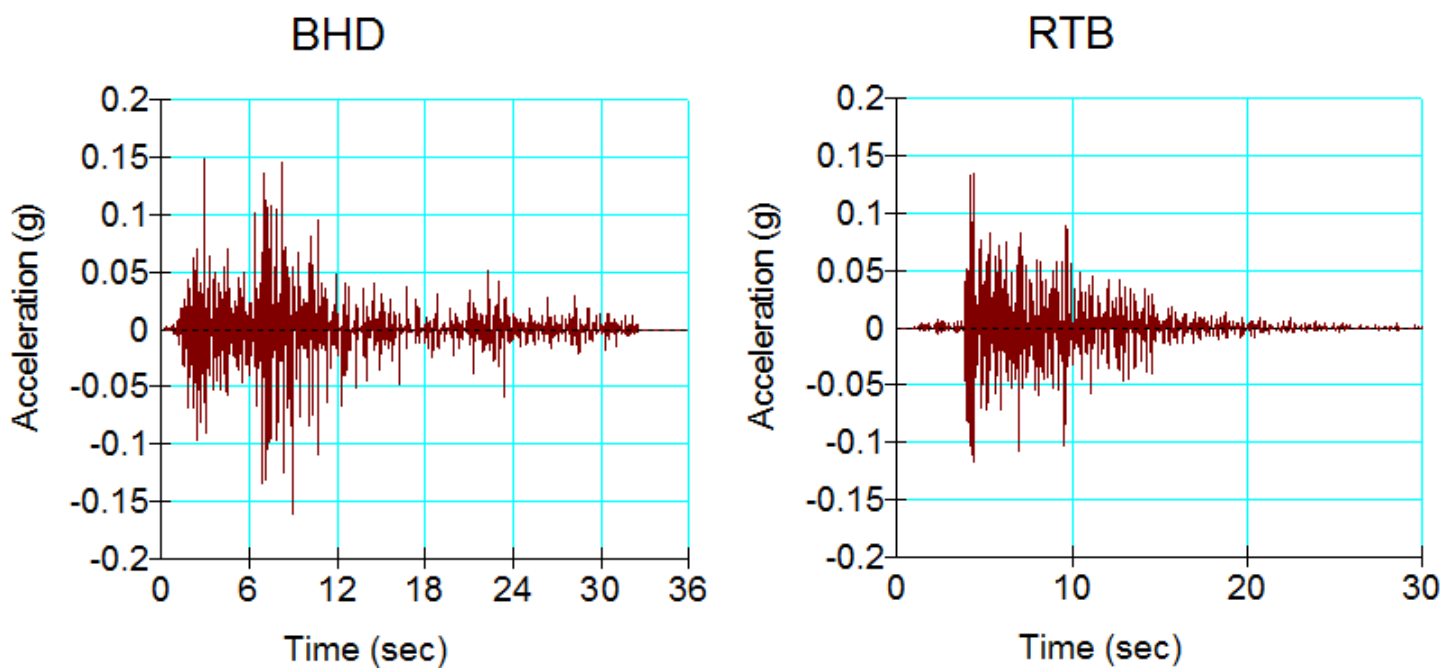

Figure 8: The Acceleration-time history records for Al-Rutba (RTB) and Baghdad (BHD) stations, [16]. Figure 9: Seismic monitoring stations Map in Iraq [16].

\section{Post-EarthQuake StabiLity}

The results of the Dynamic analysis are used as input for limit equilibrium analysis .

Upstream and downstream slopes were checked at three different levels of water, as follows:

I. Maximum levelof water.

II. Normal levelof water.

III. Minimum operational level.

Figure 10 show the factor of safety (F.S) for upstream slope stability after the earthquake of 0.161 ghorizontal accelerationfor maximum, normal and minimum water level, respectively. Figure 11 shows the F.S for upstream slope stability after an earthquake of $0.375 \mathrm{~g}$ horizontal acceleration for maximum, normal and minimum water level, respectively.Figure 12 show the F.S for downstream 
slope stability after the earthquake of $0.161 \mathrm{~g}$ horizontal acceleration for maximum, normal and minimum water level, respectively. Figure 13 shows the F.S for downstream slope stability after the earthquake of $0.375 \mathrm{~g}$ horizontal acceleration for maximum, normal and minimum water level, respectively.

Tables IV, V, and V1 show the results of the post-earthquake Haditha dam stability analysis for maximum horizontal accelerations of $0.161 \mathrm{~g}, 0.134 \mathrm{~g}$ and $0.375 \mathrm{~g}$ with various methods such as Morgenstern-Price,Spencer, Corps of Engineers \#1, \#2, Bishop, Janbu, Ordinary and QUAKE/W Stress method and comparisonwith limitations of (USACE)[17] and (BDS)[18].

Post-earthquake safety factor (F.S) of upstream and downstream slope stability values for the maximum horizontal acceleration of $0.161 \mathrm{~g}$ and $0.134 \mathrm{~g}$ fulfill minimum limits for all water levels. It can be concluded that Haditha dam is safe against seepage failure and slope failure after the earthquake for maximum horizontal accelerations $0.161 \mathrm{~g}$ and $0.134 \mathrm{~g}$ under the different levels of water presented.

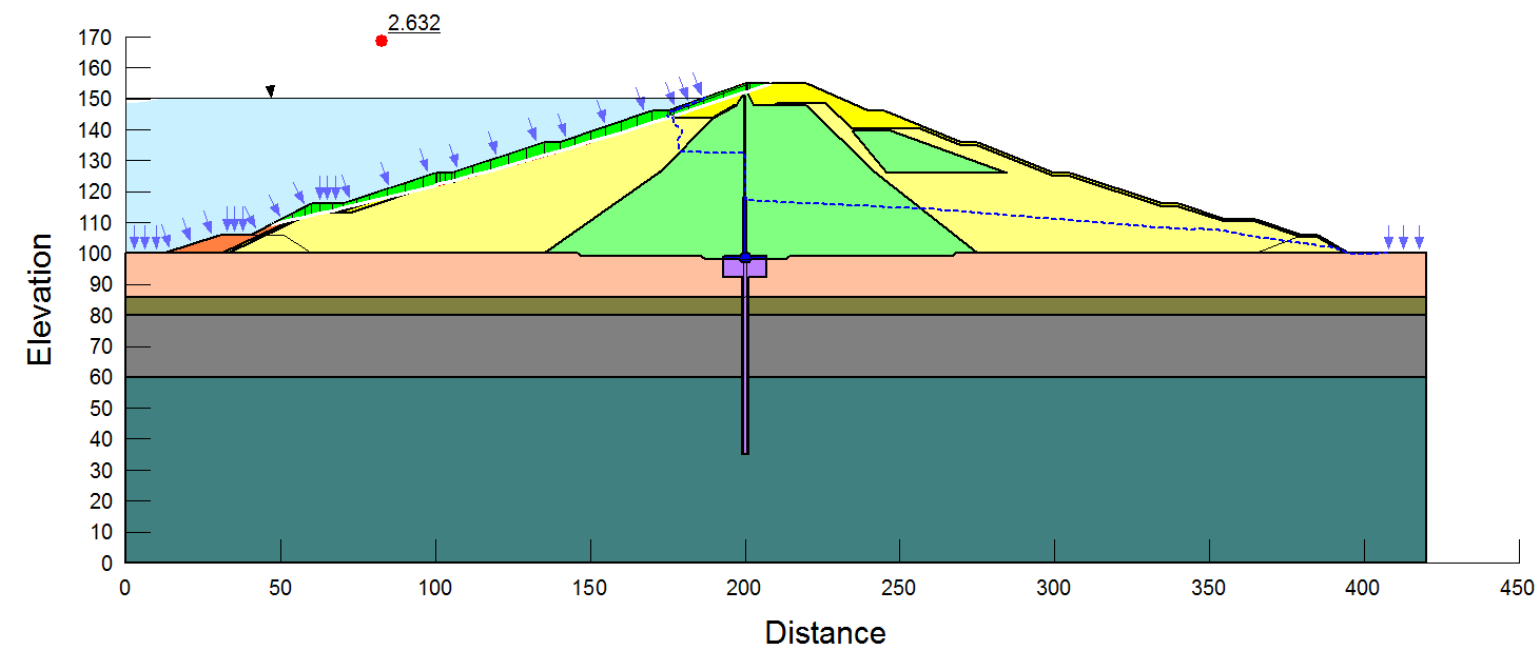

(a) Maximum level ofwater

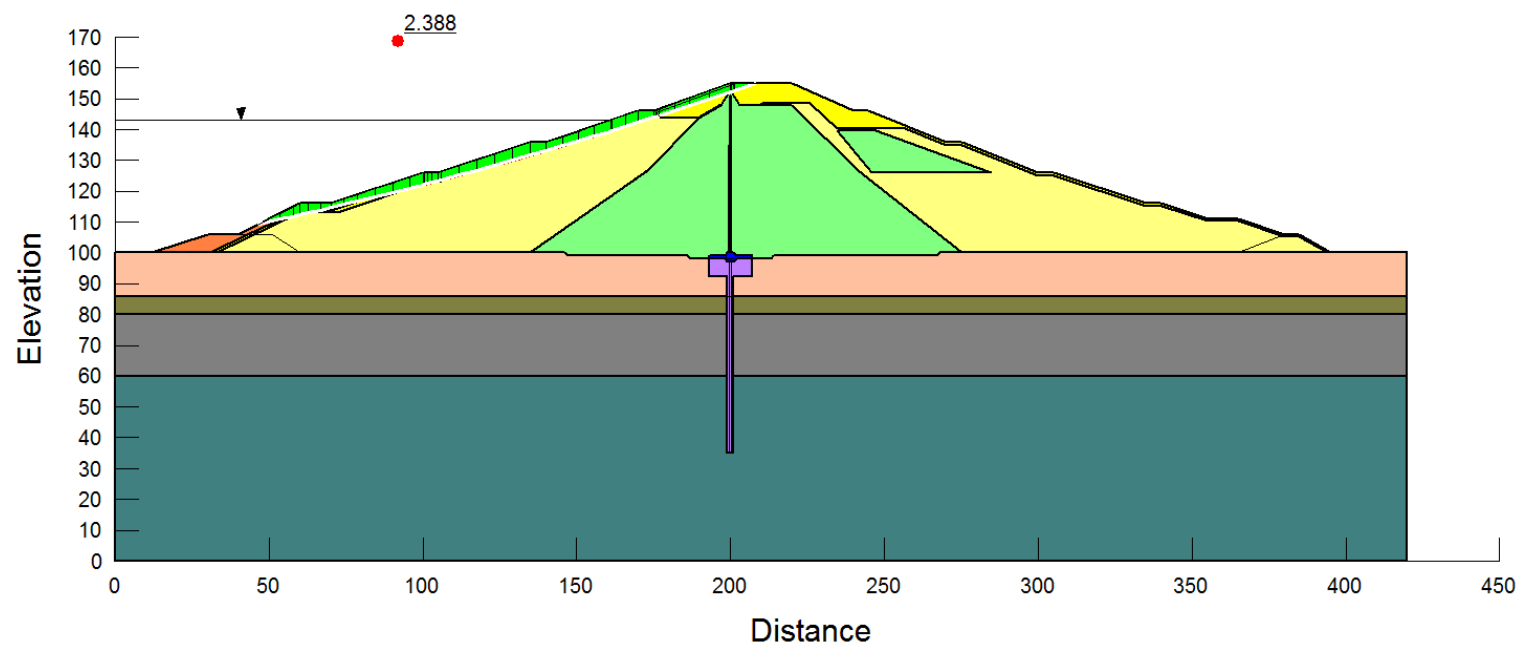

(b) Normal levelof water 


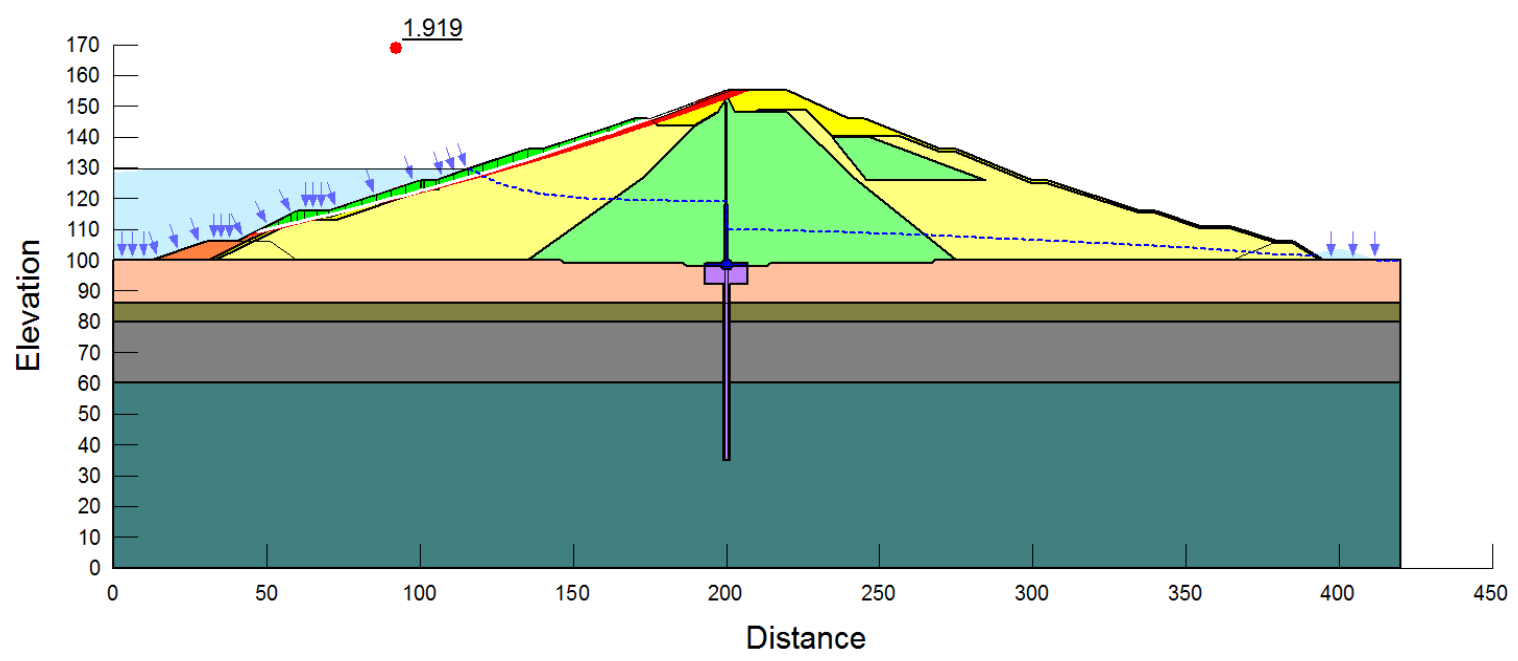

(c) Minimum levelof water

Figure 10: Factor of Safety for upstream slope stability after the earthquake of $0.161 \mathrm{~g}$ horizontal acceleration

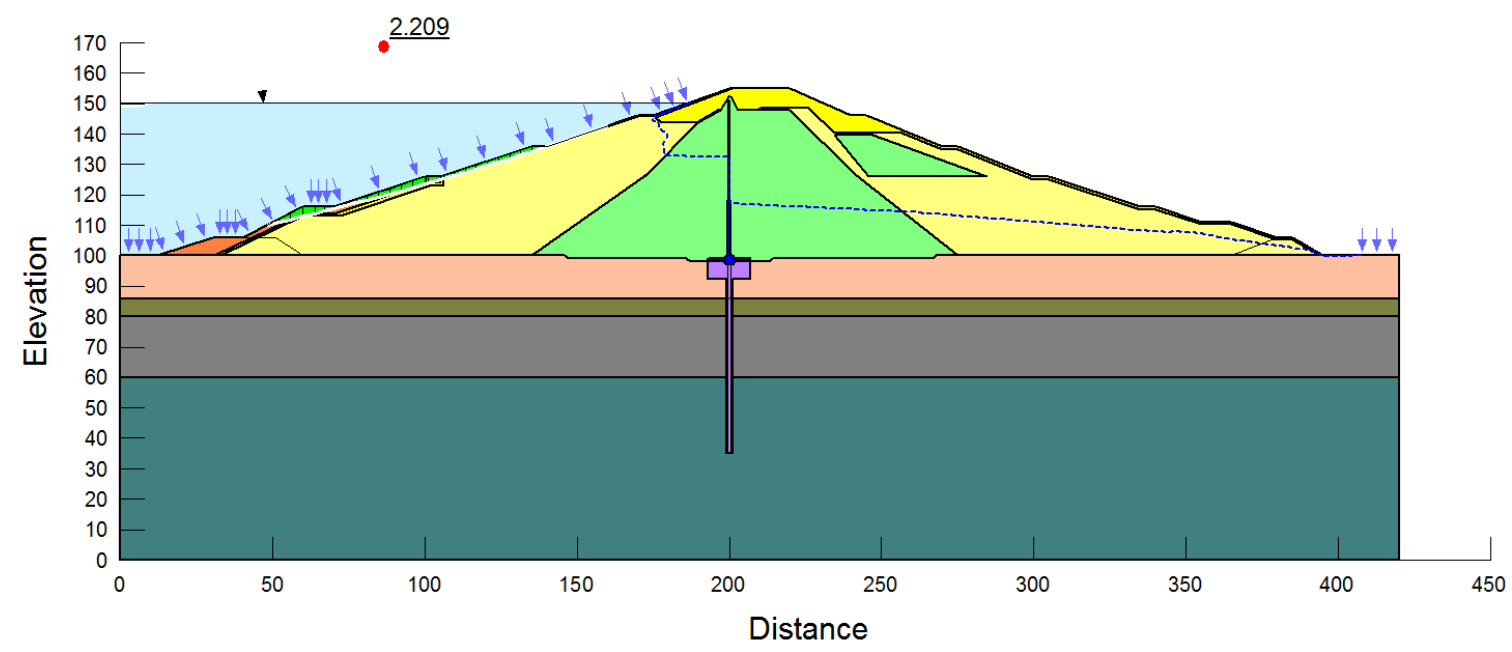

(a) Maximum levelof water

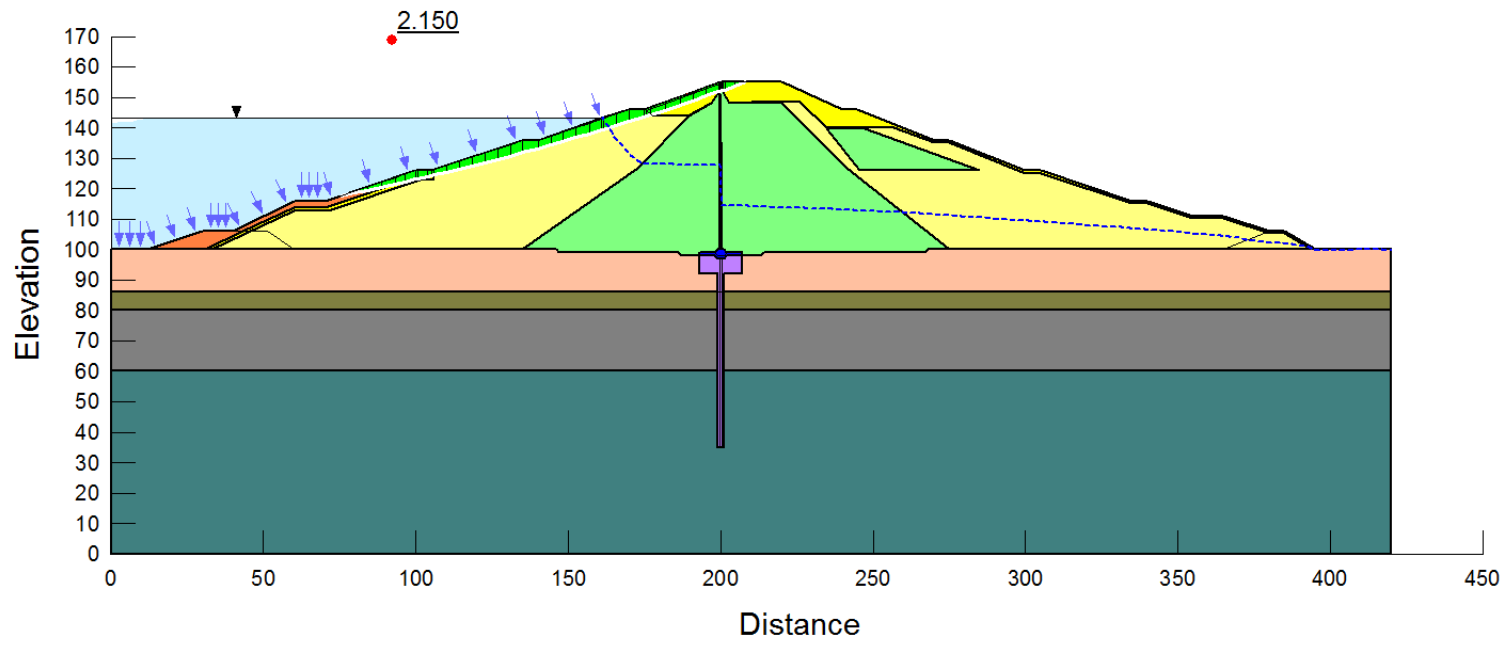

(b) Normal levelof water 


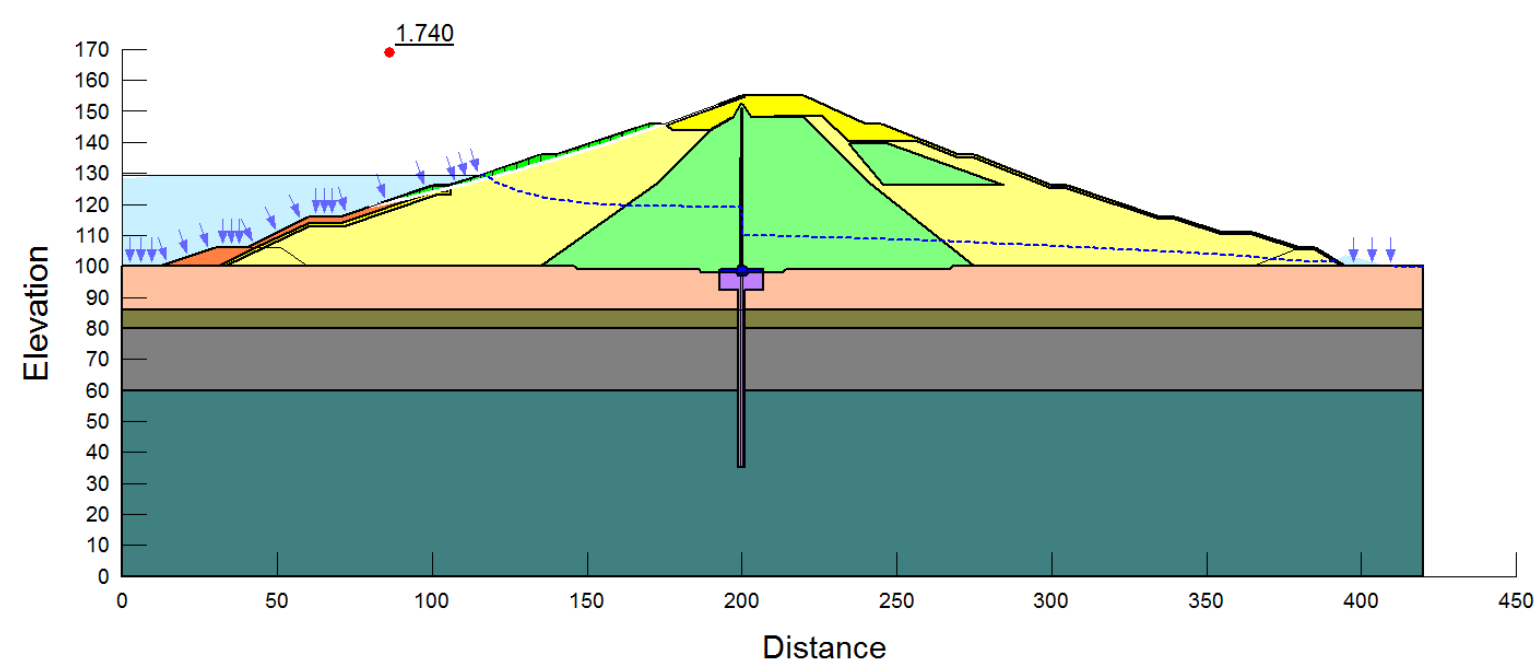

(c) Minimum levelof water

Figure 11: Factor of Safety for upstream slope stability after the earthquake of $0.375 \mathrm{~g}$ horizontal acceleration

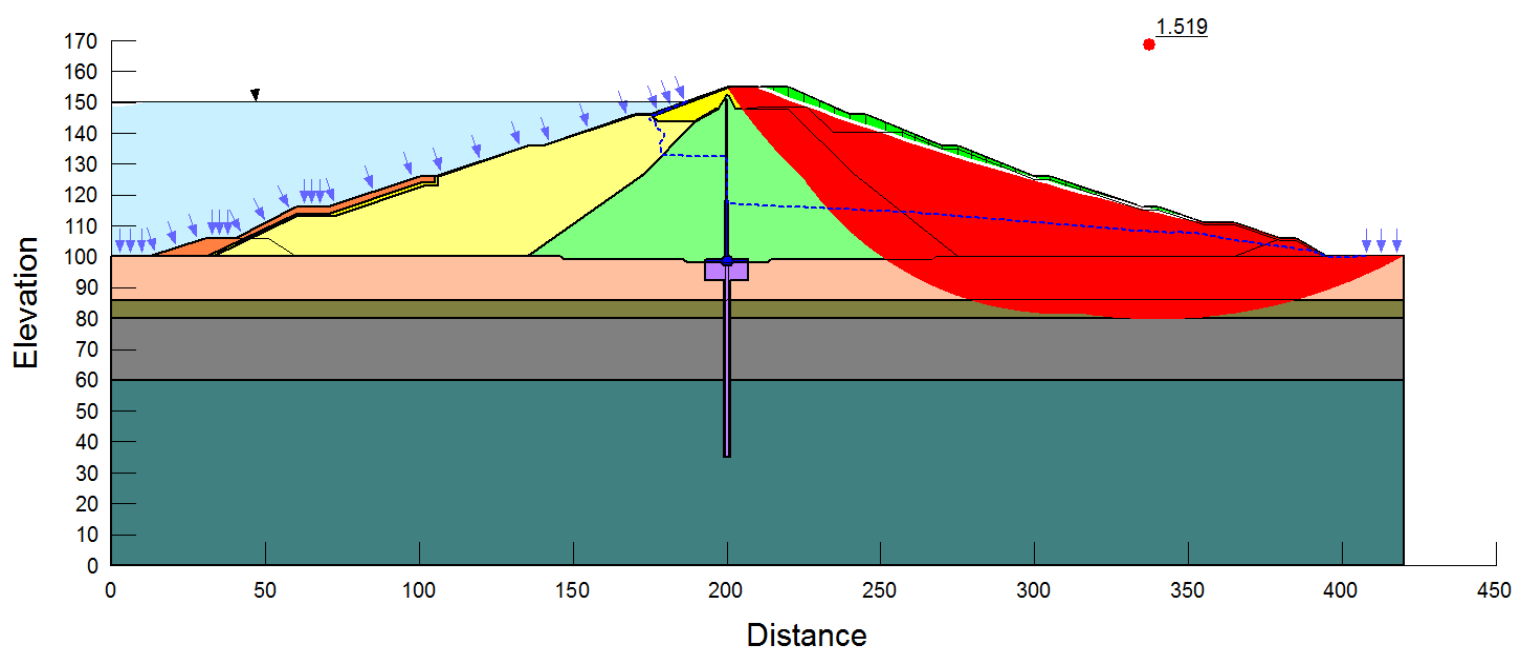

(a) Maximum levelof water

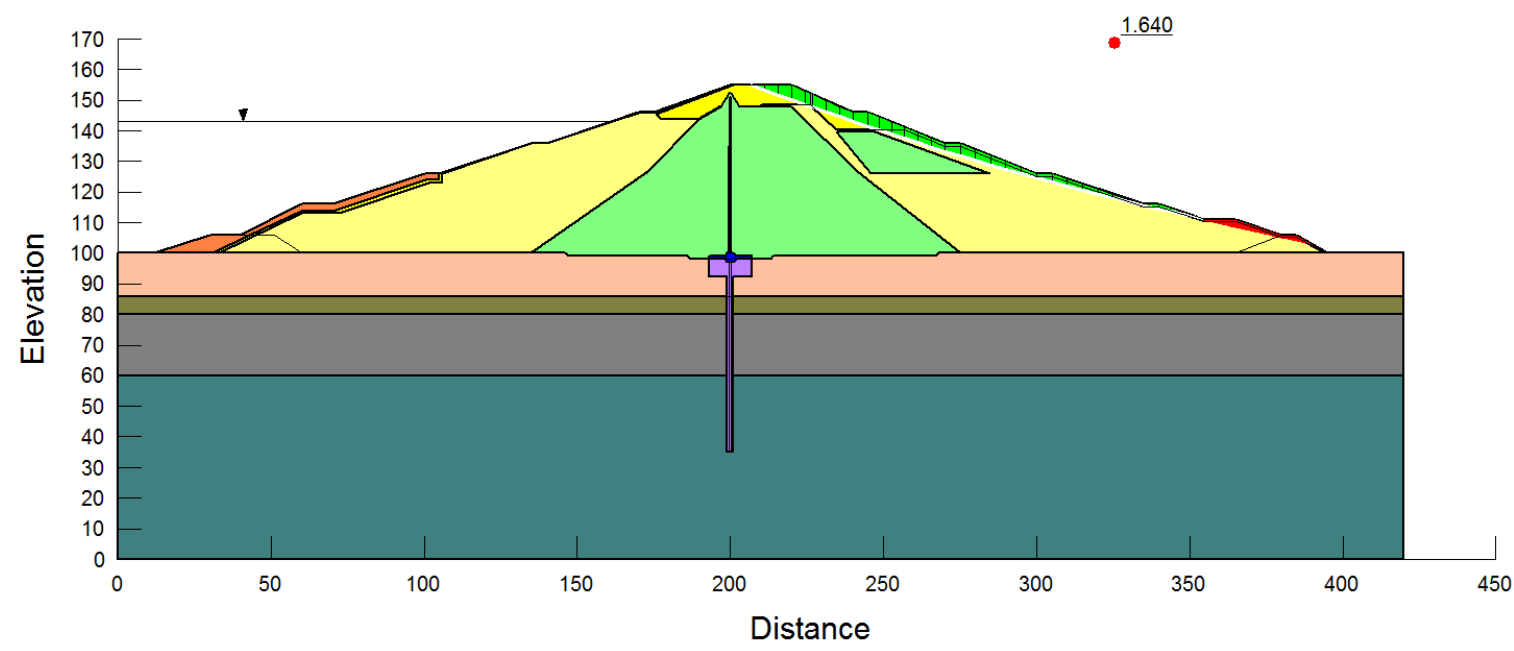

(b) Normal levelof water 


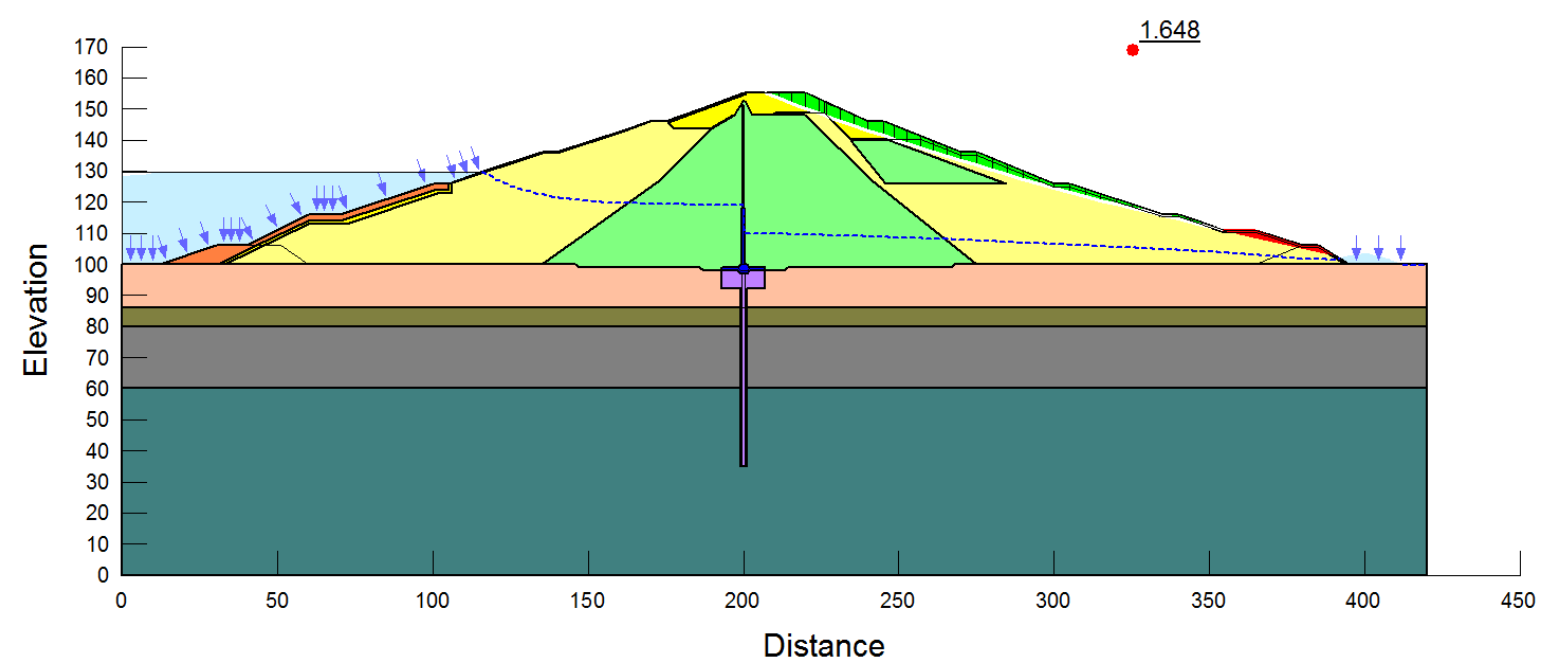

(c) Minimum levelof water

Figure 12: Factor of Safety for downstream slope stability after the earthquake of $0.161 \mathrm{~g}$ horizontal acceleration

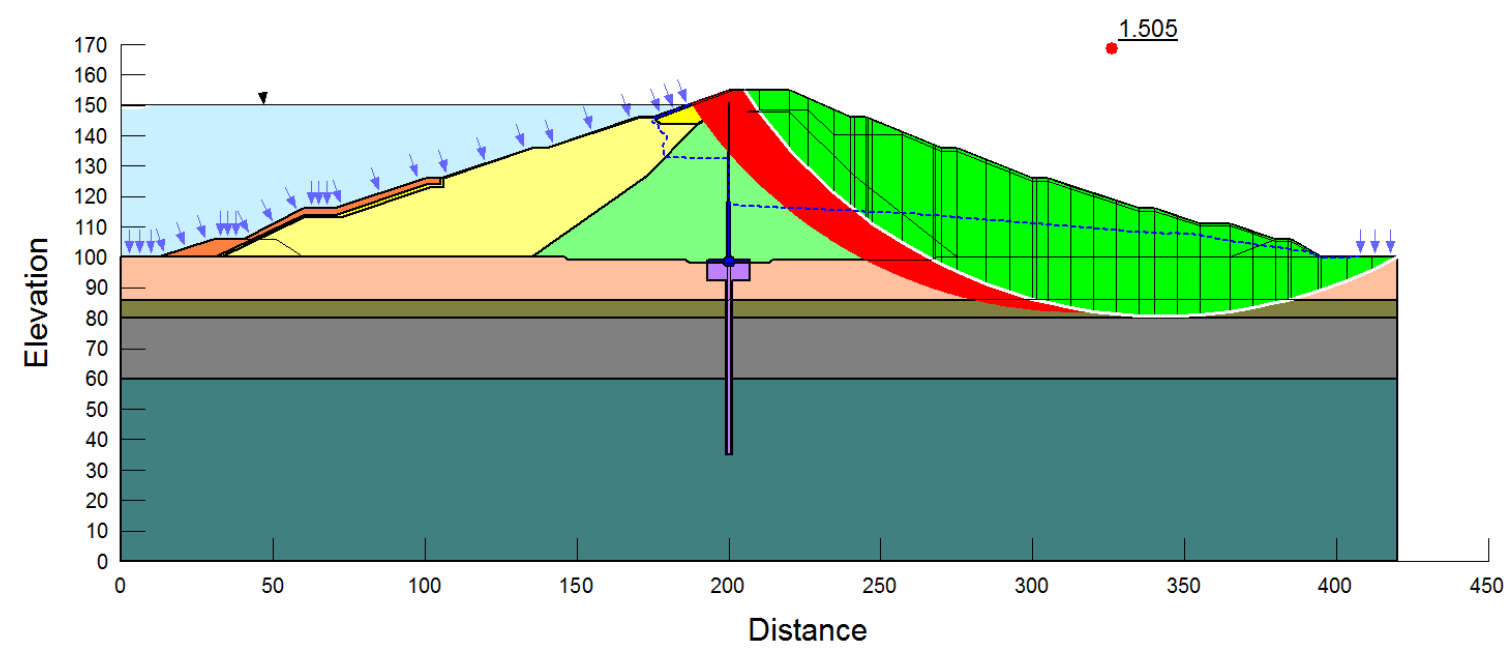

(a) Maximum water level

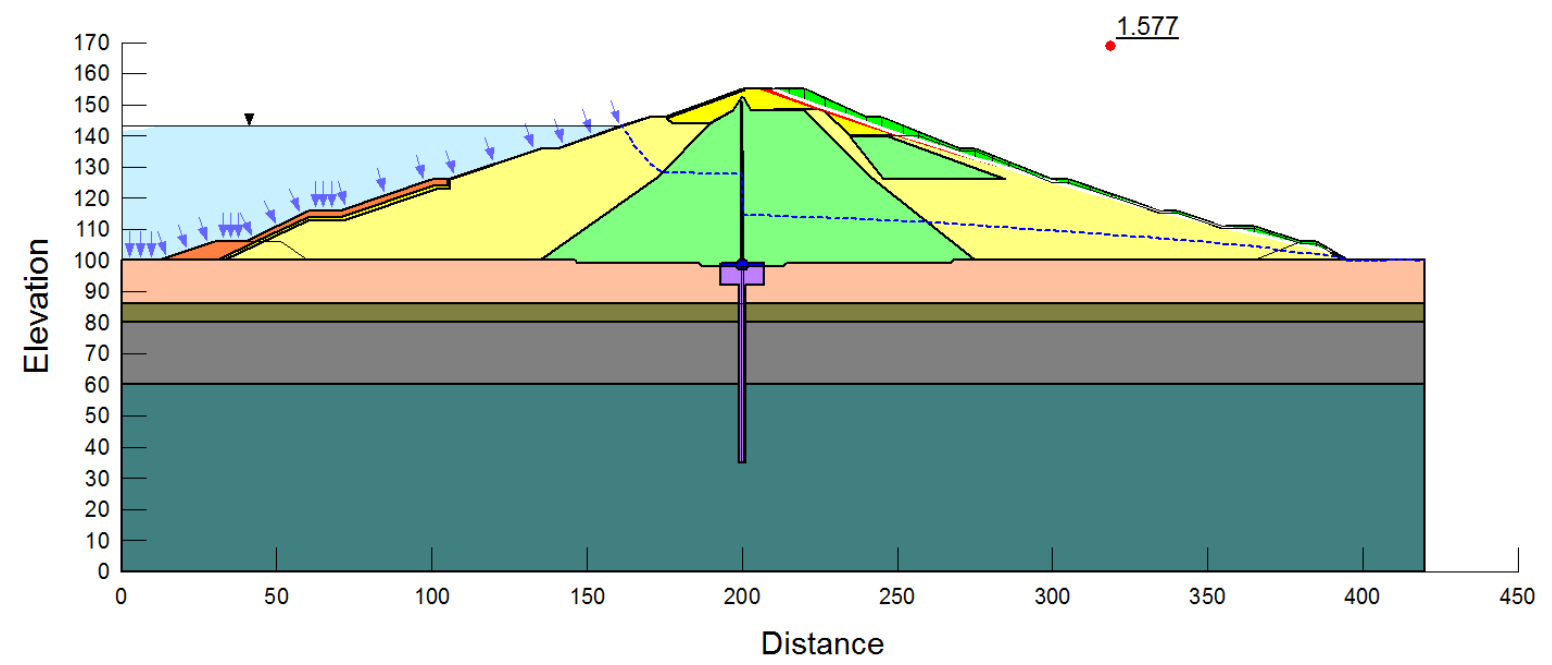

(b) Normal water level 


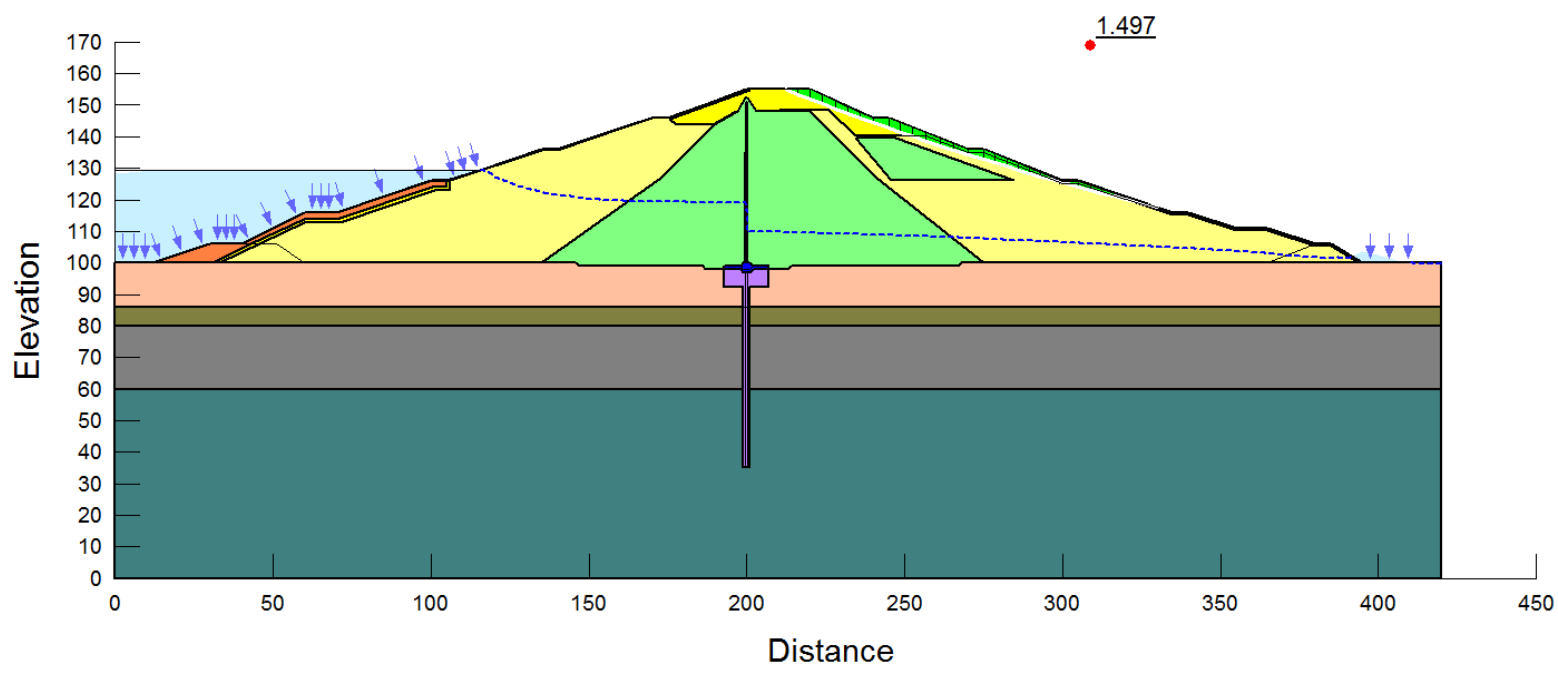

(c) Minimum water level

Figure 13: Factor of Safety for downstream slope stability after the earthquake of $0.375 \mathrm{~g}$ horizontal acceleration

TABLEIV: Results of Haditha dam stability analysis after the earthquake for maximum horizontal acceleration $0.161 \mathrm{~g}$ with limitations of (USACE 2003) and (BDS 1994).

\begin{tabular}{|c|c|c|c|c|c|c|}
\hline \multirow{2}{*}{$\begin{array}{c}\text { Critical } \\
\text { Condition for } \\
\text { Stability }\end{array}$} & \multicolumn{2}{|c|}{ Maximum water level } & \multicolumn{2}{|c|}{ Normal water level } & \multicolumn{2}{|c|}{ "Minimum water level } \\
\hline & Upstream & Downstream & Upstream & Downstream & Upstream & Downstream \\
\hline US ACE (2003) & \multicolumn{2}{|c|}{1.5} & \multicolumn{2}{|c|}{1.5} & \multicolumn{2}{|c|}{1.5} \\
\hline BDS (1994) & \multicolumn{2}{|c|}{$(1.3-1.5)$} & \multicolumn{2}{|c|}{$(1.3-1.5)$} & \multicolumn{2}{|c|}{$(1.3-1.5)$} \\
\hline $\begin{array}{l}\text { Morgenstern- } \\
\text { Price } \\
\end{array}$ & 3.099 & 1.563 & 2.672 & 1.731 & 2.029 & 1.731 \\
\hline Spencer & 3.107 & 1.567 & 2.672 & 1.731 & 2.029 & 1.731 \\
\hline $\begin{array}{c}\text { Corps of } \\
\text { Engineers \#1 } \\
\end{array}$ & 1.581 & 1.559 & 1.693 & 1.733 & 1.568 & 1.733 \\
\hline $\begin{array}{c}\text { Corps of } \\
\text { Engineers \#2 } \\
\end{array}$ & 1.555 & 1.559 & 1.781 & 1.733 & 1.626 & 1.733 \\
\hline Bishop & 3.126 & 1.548 & 2.678 & 1.733 & 2.028 & 1.733 \\
\hline Janbu & 2.791 & 1.511 & 2.599 & 1.712 & 1.938 & 1.730 \\
\hline Ordinary & 2.459 & 1.501 & 2.566 & 1.692 & 1.898 & 1.730 \\
\hline $\begin{array}{c}\text { QUAKE/W } \\
\text { Stress }\end{array}$ & 2.632 & 1.519 & 2.388 & 1.640 & 1.919 & 1.648 \\
\hline
\end{tabular}

TABLEV: Results from the post-earthquake Haditha dam stability analysis of the maximum horizontal acceleration of $0.134 \mathrm{~g}$ with limitations (USACE 2003) and (BDS 1994).

\begin{tabular}{|c|c|c|c|c|c|c|}
\hline \multirow{2}{*}{$\begin{array}{c}\text { Critical } \\
\text { Condition for } \\
\text { Stability } \\
\end{array}$} & \multicolumn{2}{|c|}{ "Maximum water level } & \multicolumn{2}{|c|}{ Normal water level } & \multicolumn{2}{|c|}{ Minimum water level } \\
\hline & Upstream & Downstream & Upstream & Downstream & Upstream & Downstream \\
\hline US ACE (2003) & \multicolumn{2}{|c|}{1.5} & \multicolumn{2}{|c|}{1.5} & \multicolumn{2}{|c|}{1.5} \\
\hline BDS (1994) & \multicolumn{2}{|c|}{$(1.3-1.5)$} & \multicolumn{2}{|c|}{$(1.3-1.5)$} & \multicolumn{2}{|c|}{$(1.3-1.5)$} \\
\hline $\begin{array}{l}\text { Morgenstern- } \\
\text { Price }\end{array}$ & 3.099 & 1.524 & 2.672 & 1.731 & 2.029 & 1.731 \\
\hline Spencer & 3.107 & 1.534 & 2.672 & 1.731 & 2.029 & 1.731 \\
\hline $\begin{array}{c}\text { Corps of } \\
\text { Engineers \#1 } \\
\end{array}$ & 1.553 & 1.559 & 1.693 & 1.733 & 1.568 & 1.733 \\
\hline $\begin{array}{c}\text { Corps of } \\
\text { Engineers \#2 }\end{array}$ & 1.536 & 1.559 & 1.781 & 1.733 & 1.626 & 1.733 \\
\hline Bishop & 3.100 & 1.548 & 2.676 & 1.733 & 2.028 & 1.733 \\
\hline
\end{tabular}




\begin{tabular}{ccccccc}
\hline Janbu & 2.787 & 1.511 & 2.599 & 1.712 & 1.938 & 1.730 \\
\hline Ordinary & 2.512 & 1.501 & 2.566 & 1.692 & 1.898 & 1.730 \\
\hline $\begin{array}{c}\text { QUAKE/W } \\
\text { Stress }\end{array}$ & 2.659 & 1.519 & 2.388 & 1.640 & 1.919 & 1.648 \\
\hline
\end{tabular}

TABLEVI: Results of Haditha dam stability analysis after the earthquake for maximum horizontal acceleration $0.375 \mathrm{~g}$ with limitations of (USACE 2003) and (BDS 1994).

\begin{tabular}{|c|c|c|c|c|c|c|}
\hline \multirow{2}{*}{$\begin{array}{c}\text { Critical } \\
\text { Condition for } \\
\text { Stability }\end{array}$} & \multicolumn{2}{|c|}{ Maximum water level } & \multicolumn{2}{|c|}{ Normal water level } & \multicolumn{2}{|c|}{ Minimum water level } \\
\hline & Upstream & Downstream & Upstream & Downstream & Upstream & Downstream \\
\hline US ACE (2003) & \multicolumn{2}{|c|}{1.5} & \multicolumn{2}{|c|}{1.5} & \multicolumn{2}{|c|}{1.5} \\
\hline BDS (1994) & \multicolumn{2}{|c|}{$(1.3-1.5)$} & \multicolumn{2}{|c|}{$(1.3-1.5)$} & \multicolumn{2}{|c|}{$(1.3-1.5)$} \\
\hline $\begin{array}{l}\text { Morgenstern- } \\
\text { Price }\end{array}$ & 3.028 & 1.498 & 2.623 & 1.672 & 1.924 & 1.654 \\
\hline Spencer & 3.029 & 1.508 & 2.623 & 1.672 & 1.924 & 1.654 \\
\hline $\begin{array}{c}\text { Corps of } \\
\text { Engineers \#1 }\end{array}$ & 1.435 & 1.548 & 1.670 & 1.673 & 1.543 & 1.655 \\
\hline $\begin{array}{c}\text { Corps of } \\
\text { Engineers \#2 }\end{array}$ & 1.436 & 1.558 & 1.638 & 1.673 & 1.007 & 1.656 \\
\hline Bishop & 2.901 & 1.534 & 2.394 & 1.673 & 1.942 & 1.656 \\
\hline Janbu & 2.791 & 1.404 & 2.386 & 1.661 & 1.885 & 1.653 \\
\hline Ordinary & 2.456 & 1.371 & 2.471 & 1.647 & 1.854 & 1.653 \\
\hline $\begin{array}{c}\text { QUAKE/W } \\
\text { Stress }\end{array}$ & 2.209 & 1.505 & 2.150 & 1.577 & 1.740 & 1.497 \\
\hline
\end{tabular}

\section{CONCLUSION}

The safety check of the dam was based on the minimum required safety factor(F.S) as indicated in (USACE) and (BDS). The results indicate that F.S of post-earthquake stability values for upstream and downstream slopes fulfill the minimum standard limits for all water levels for $0.134 \mathrm{~g}$ and $0.161 \mathrm{~g}$ maximum horizontal acceleration., while it is noted that the F.S values of upstream and downstream slopes stability under earthquakes with maximum horizontal acceleration $0.375 \mathrm{~g}$ caused a significant decrease in F.S of upstream and downstream slope stability values and their decline less than the minimum limits, especially using (Morgenstern-Price, Corps of Engineers \#1 \& \#2, Janbu, Ordinary and QUAKE/W Stress methods, which means the failure of the dam in terms of the slope stability according to these methods, but the supposed earthquakeis of high maximum horizontal acceleration $(0.375 \mathrm{~g})$ compared to what has been recorded in recent years, this gives an indication that the dam is safe even with the changes of the seismic condition in Iraq.

\section{References}

[1] R. H. Irzooqi, Investigation and Analysis of Seepage Problems on the Left Side of Al-Qadisiya Dam, Ph. D. Thesis., Civil. Dept., Univ. Technol., Baghdad, Iraq, (1998).

[2] S, R.A. Performance of the right side of Al-Qadisiya Dam, M.Sc. thesis, Tikrit University, Tikrit, Iraq. (2000) 64.

[3] Al-Tae'e, A. Y. Y, Dynamic Response of Embankments and Dams by the Finite Element Method, M.Sc. Thesis, Civil Eng. Dept., College of Eng, Univ. of Baghdad. Iraq. (2001)

[4] A. Elgamal, Z. Yang, K. Adalier, M. K. Sharp, Effect of rigid containersize on dynamic earth dam response in centrifuge experiments, Struct. Eng. Conf., ( 2003) 1-9.

[5] K. Adalier, M. K .Sharp, Dynamic Behavior of Embankment Dam on Liquefiable Foundation Subject To Moderate Earthquake Loading, Conf. Earth. Eng., (2001) 1025.

[6] S. A. Hadi, Effect of Earthquake on Earth-fill Dams ( Khassa Chai Dam as Case Study ), 5.

[7] A.H. M. Hassan, I. Hassan, 2016. An Analytical Study of the Effect of Earthquakes on Embankment Dams Using the Finite Element Method Case Study: El-Bassel Dam / Tartous. Tishreen Univ. J.for Research and Scientific Studies 3: 529-45.

[8] A. M. I. Al-Shamary, Evaluation of Seepage through Haditha Dam West of Iraq, M.Sc. thesis, College Sci.,Univ. of Tikrit, Salahudeen, Iraq, 2019. 
[9] Lu . Likos, Unsaturated Soil Mechanics, John Wiley \& Sons, Inc., New York,2007.

[10] K. John, Revision Stability Modeling with SLOPE/W, 1 An Eng. Method., Edition., 2012.

[11] N. Adamo, V. K. Sissakian, N. Al-Ansari, M. Elagely, S. Knutsson, J. Laue Comparative Study of Mosul and Haditha Dams in Iraq: Different, Const. Mater. Contr. Differ. Des. J. Earth. Sci. Geotech. Eng., 8 (2018) 1792-9660.

[12] Haditha Dam Project, Technical report on Haditha Dam, Dams and Reservoirs Authority, Ministry of Water Resources, Baghdad, Iraq, 1995.

[13] M. Cosentino, Correlation between the Modified Mercalli seismic scale and the Medvedev-SponheuerKarnik scale for the earthquakes of Sicily and Calabria, 1980.

[14] J. D. Rice, Summaries of Case Histories. Chapter (3), scholar. lib. vt. edu/theses/available/etd-1210(2007), 2007.

[15] Haditha Dam Project, Technical report on Haditha Dam, Dams and Reservoirs Authority, Ministry of Water Resources, Baghdad, Iraq, 2020

[16] Seismic Monitoring Division, General Authority for Meteorology and Seismic Monitoring, Baghdad, Iraq, 2020.

[17] USACE, Slope Stability, Engineering Manual 1110-2-1902, Dept. of the Army, Corps of Engineers, Washington DC, United States of America,2003.

[18] BDS, The British Dam Society at the Institution of Civil engineers, Great George Street, London, SW 1P 3AA, (1994).

[19] R. H. Irzooqi, Investigation and Analys is of Seepage Problems on the Left Side of Al-Qadisiya Dam, Ph. D. Thesis, Civil Dept., Univ. of Technolgy, Baghdad, Iraq, (1998).

[20] Salih, R.A. Performance of the right side of Al-Qadisiya Dam, M.Sc. thesis, Tikrit University, Tikrit, Iraq, 64 (2000).

[21] Al-Tae'e, A. Y. Y, Dynamic Response of Embankments and Dams by the Finite Element Method, M.Sc. Thesis, Civil Eng. Dept., College of Eng, Univ. of Baghdad. Iraq. (2001).

[22] A. Elgamal, Z. Yang, K. Adalier, M. K. Sharp, Effect of rigid container size on dynamic earth dam response in centrifuge experiments, Eng. Mec. Conf., (2003) 1-9. 